\title{
Strategi Komunikasi Sains LIPI dalam Kegiatan Diseminasi Pupuk Organik Hayati Kepada Masyarakat
}

\section{LIPI Science Communication Strategy in Biological Organic Fertilizer Dissemination Activities to the Community}

\author{
Kapat Yuriawan ${ }^{1,3^{*}}$, Sarwititi Sarwoprasodjo ${ }^{2}$, Dyah Rachmawati Sugiyanto ${ }^{3}$
}

\author{
${ }^{1}$ Mahasiswa Pascasarjana Prodi Komunikasi Pembangunan Pertanian dan Pedesaan, Institut Pertanian Bogor, Indonesia \\ ${ }^{2}$ Staf Pengajar Komunikasi Pembangunan Pertanian dan Pedesaan, Institut Pertanian Bogor, Indonesia \\ ${ }^{3}$ Staf Biro Kerjasama Hukum dan Humas, LIPI, Indonesia \\ ${ }^{*}$ E-mail korespondensi: kapatyuriawan@yahoo.co.id
}

Diterima: 05 Juli 2021 | Disetujui: 26 Agustus 2021 | Publikasi online: 17 September 2021

\begin{abstract}
Research institutions in Indonesia have an important role in improving knowledge, skills, and the economy of the community through the use of research results. However, until now, the results of domestic research have not been well disseminated. One of the factors that influence it is the not yet optimal collaboration between researchers and public relations as science communicators in communicating research results to the public. This study uses qualitative method with case study approach of dissemination of Beyonic Startmik-LIPI Biological Organic Fertilizer in 2021. The study used the primary data source of conversations between researchers and publicists through whatsapp media. Interview techniques are conducted online through zoom meetings. In analyzing conversations between researchers and public relations, this study uses Coordinated Meaning Management Theory. Secondary data sources are obtained through dissemination activity report documents as well as POH Beyonic Startmik-LIPI news on the website. The results showed the communication strategy of public relations and researchers in the dissemination activities of $\mathrm{POH}$ Beyonik Startmik through three stages, namely: (1) the preparation stage includes coordinating schedule information and confirmation of resource persons, (2) the implementation stage shall include coordinating the preparation of the trip and the presentation method, (3) the evaluation stage shall include coordinating the preparation of news content.
\end{abstract}

Keywords: Communication science, researchers, public relations, coordinated meaning management, dissemination

\section{ABSTRAK}

Lembaga penelitian di Indonesia memiliki peran penting dalam meningkatkan pengetahuan, keterampilan, dan perekonomian masyarakat melalui pemanfaatan hasil penelitian. Namun, hingga saat ini, hasil penelitian dalam negeri belum disebarluaskan dengan baik. Salah satu faktor yang mempengaruhinya adalah belum optimalnya kolaborasi antara peneliti dan humas sebagai komunikator sains dalam mengkomunikasikan hasil penelitian kepada publik. Penelitian ini menggunakan metode kualitatif dengan pendekatan studi kasus diseminasi Pupuk Organik Hayati Beyonic Startmik-LIPI tahun 2021. Penelitian ini menggunakan sumber data primer percakapan antara peneliti dan humas melalui media whatsapp. Teknik wawancara dilakukan secara daring melalui zoom meeting. Dalam menganalisa percakapan antara peneliti dan humas, penelitian ini menggunakan Teori Manajemen Makna Terkoordinasi. Sumber data sekunder diperoleh melalui dokumen laporan kegiatan diseminasi serta pemberitaan POH Beyonic Startmik-LIPI di website. Hasil penelitian menunjukkan strategi komunikasi humas dan peneliti dalam kegiatan diseminasi POH Beyonik Startmik melalui tiga tahapan yaitu: (1) tahap persiapan meliputi pengkoordinasian penginformasian jadwal dan konfirmasi narasumber, (2) tahap pelaksanaan meliputi pengkoordinasian persiapan perjalanan dan metode presentasi, (3) tahap evaluasi meliputi pengkoordinasian penyusunan konten berita.

Kata kunci: Komunikasi sains, peneliti, humas, manajemen makna terkoordinasi, diseminasi 


\section{PENDAHULUAN}

Salah satu misi pembangunan nasional adalah mewujudkan bangsa yang berdaya saing melalui kegiatan penelitian, pengembangan dan penerapan ilmu pengetahuan dan teknologi (iptek) menuju inovasi yang berkelanjutan. Menurut US Council of Competitiveness, kegiatan riset dan teknologi merupakan sektor produktif dalam investasi dan berpengaruh besar dalam menentukan daya saing bangsa. Sedangkan dalam rangka penguasaan iptek dan kemampuan inovasi yang dimiliki oleh sebuah negara, World Economic of Forum (WEF) menyampaikan bahwa kesiapan teknologi (technological readiness) merupakan salah satu pilar penilaian daya saing suatu negara yang mampu menjamin pertumbuhan ekonomi nasional yang kuat, mandiri dan berdaya saing tinggi.

Lembaga penelitian dan pengembangan (litbang) memiliki peran besar dalam menyebarkan hasil-hasil riset guna meningkatkan pengetahuan dan perekonomian masyarakat. Namun hingga kini, permasalahan hilirisasi hasil-hasil riset masih menjadi kendala utama dunia litbang di Indonesia. Selama ini hasil-hasil penelitian yang dilakukan oleh para peneliti baik di lembaga litbang maupun perguruan tinggi terkesan hanya terhenti pada publikasi di jurnal ilmiah dan hanya dipresentasikan dalam forum ilmiah (Astirin, 2018). Menurut Putri (2014) selama ini hasil-hasil penelitian hanya mampu diakses oleh kalangan ilmiah saja. Oleh karena itu, masyarakat awam tidak memiliki akses untuk mendapatkan informasi tentang hasil penelitian tersebut. Selama ini sains dan teknologi masih dipandang sebagai sesuatu yang eksklusif dan rumit di Indonesia.

Agar iptek dan hasil-hasil riset tersebut dapat tersampaikan kepada publik, dibutuhkan komunikasi sains. Menurut Gascoigne \& Metcalfe (2017) faktor yang melatar belakangi lahirnya komunikasi sains adalah keinginan agar sains lebih dipahami secara luas, lebih menarik, bermanfaat bagi bangsa dan lebih akuntabel untuk kepentingan publik. Berdasarkan pernyataan tersebut sangat jelas bahwasanya komunikasi sains memiliki cakupan yang lebih luas karena berorientasi pada kebutuhan publik bukan semata komunitas ilmiah saja, sedangkan tujuan dari komunikasi sains menurut Weingart \& Joubert (2019) adalah untuk meningkatkan pemahaman publik, membuat sains dapat diakses, mengamankan dukungan politik berkelanjutan, secara demokratis memperhitungkan penggunaan dana publik, dan memungkinkan partisipasi publik dalam proses sains dan teknologi.

Dalam pendiseminasian hasil riset kepada masyarakat, diperlukan perencanaan dan strategi komunikasi terpadu antara peneliti dengan pemangku kebijakan lainnya. Beidas \& Kendall, (2014) menyebutkan bahwa diseminasi adalah distribusi informasi dan materi intervensi yang ditargetkan untuk khalayak tertentu yang bertujuan untuk menyebarkan (meningkatkan) dan mempertahankan pengetahuan dan intervensi berbasis bukti. Strategi komunikasi merupakan tahapan konkret dalam rangkaian aktivitas komunikasi yang berbasis pada teknik pengimplementasian tujuan komunikasi. Strategi komunikasi selalu dihubungkan dengan siapa yang bicara apa, dengan maksud apa, ditujukan untuk siapa, bagaimana menyampaikan pesan, serta bagaimana dampak pesan yang disampaikan tersebut (Nurhayati et al., 2018).

Selain strategi komunikasi, dalam rangka menyukseskan diseminasi hasil riset kepada masyarakat, dibutuhkan peran koordinasi dan kerjasama antara peneliti dan Sumber Daya Manusia (SDM) pendukung iptek lainnya. Hubungan Masyarakat (Humas) merupakan salah satu SDM pendukung iptek di lembaga litbang yang memiliki peran penting dalam menyampaikan hasil-hasil riset kepada masyarakat. Humas menjadi sosok penting dalam menjembatani peneliti dengan pemangku kepentingan seperti pemerintah daerah, anggota dewan, dunia industri, universitas, kelompok masyarakat serta sektor swasta lainnya. Humas juga memiliki keterampilan untuk menyampaikan hasil-hasil riset ke dalam bahasa umum yang mudah dipahami oleh masyarakat umum.

Menurut penelitian yang dilakukan oleh Sugiyanto (2016), humas di lembaga ilmiah berperan sebagai komunikator iptek yang dituntut untuk mempunyai keahlian dalam berdialog dengan publik mengenai identitas lembaga, tanggungjawab lembaga, dan hasil-hasil penelitian serta manfaatnya kepada publik. Kolaborasi antar peneliti dengan humas mampu menciptakan sebuah komunikasi sains yang efektif. Menurut Autzen (2014) disebutkan bahwa dalam konteks komunikasi sains humas dan peneliti saling berdampingan bahkan berbagi fungsi dalam upaya mengenalkan hasil-hasil riset kepada publik.

Keterlibatan humas dengan peneliti dalam mengkomunikasikan hasil penelitian merupakan fungsi humas dalam pelayanan informasi publik sebagai upaya membangun kepercayaan publik terhadap lembaga. Menurut Mohi (2015) kegiatan diseminasi hasil riset yang dilakukan humas adalah dalam rangka melayani kepentingan publik yang pada akhirnya akan membentuk citra lembaga. Penelitian yang dilakukan oleh Sarwoprasodjo (2009) menyatakan bahwa komunikasi persuasif yang dilakukan oleh humas pemerintah 
dalam mensosialisasikan program dan kebijakan di media massa mampu menanamkan citra kinerja pemerintah di mata publik.

Beberapa kajian tentang komunikasi sains telah banyak dilakukan sebelumnya. Penelitian tentang media pendiseminasian hasil penelitian dilakukan oleh, Adriyani (2019). Dalam penelitiannya, Adriyani menyebutkan bahwa aplikasi Cyber extension paling banyak dimanfaatkan oleh penyuluh di Kota Metro (47 materi) sedangkan kendala yg dihadapi adalah rendahnya keterampilan dan kemauan penyuluh untuk menulis materi penyuluhan di media tersebut. Zhang et al. (2016) juga mengkaji tentang media diseminasi berbasis IT yang digunakan oleh pemerintah China yaitu portal web, layanan telephone/call center, layanan SMS, komunitas online, layanan video interaktif, smartphone, serta layanan terpadu/telephone. Sedangkan menurut Irawan et al. (2015), menyatakan bahwa Inovasi teknologi melalui SDMC (spectrum disseminate model communication) mampu mengatasi berbagai permasalahan petani lahan kering masam. Gartina (2015) dalam penelitiannya juga menyebutkan pengemasan informasi inovasi pada media website perlu disampaikan menggunakan bahasa popular sehingga mudah dipahami oleh publik pengguna.

Terkait dengan rumusan masalah dalam penelitian ini, penelitian terdahulu tentang strategi komunikasi serta pendekatan diseminasi telah dilakukan oleh Irfan et al. (2019) dan Sofyan (2019). Dalam penelitiannya, Irfan menyebutkan bahwa diseminasi yang dilakukan oleh litbang iptek nuklir BATAN dengan metode demonstrasi farm, penangkaran padi, dan penyebaran benih padi hasil penangkaran berhasil meningkatkan produktifitas padi petani. Sedangkan hasil penelitian Sofyan menyebutkan bahwa strategi komunikasi dilakukan melalui empat tahapan yaitu sosialisasi, peran poktan, demplot dan pendampingan. Pendekatan komunikasi dilakukan dengan cara komunikasi interpersonal, kelompok, opinion leader dan gethok tular.

Berdasarkan hasil penelitian dan kajian tentang strategi komunikasi diseminasi di atas, hanya membahas tentang metode yang digunakan, tahapan atau proses diseminasi, media diseminasi, serta pendekatan komunikasi. Oleh karenanya perlu dilakukan sebuah penelitian yang mengkaji tentang strategi komunikasi yang dilakukan oleh komunikator sains dalam mendiseminasikan hasil penelitian kepada masyarakat. Penelitian ini bertujuan untuk menganalisis bagaimana peneliti dan humas LIPI memaknai serta mengkoordinasikan pesan pada saat melakukan strategi komunikasi dalam pendiseminasian $\mathrm{POH}$ beyonic Startmik kepada masyarakat.

Guna mengetahui pemaknaan tentang komunikasi sains yang dimiliki oleh peneliti dan humas, penelitian ini menggunakan teori Manajemen Makna Terkoordinasi (Coordinated Management of Meaning). Teori ini secara umum merujuk pada bagaimana individu-individu menetapkan aturan untuk menciptakan dan menginterpretasikan makna, dan bagaimana aturan-aturan tersebut terjalin dalam sebuah percakapan di mana makna senantiasa dikoordinasikan (West \& Turner, 2009).

Menurut Pearce (2009) terdapat tiga asumsi dasar dalam teori ini yaitu, (1) manusia hidup dalam komunikasi, Pearce berpendapat bahwa komunikasi adalah, dan akan selalu, menjadi lebih penting bagi manusia dari yang seharusnya, (2) Manusia saling menciptakan realitas sosial, dan (3) Transaksi informasi yang terjadi dalam komunikasi tersebut dipengaruhi oleh makna pribadi dan makna interpersonal.

Teori ini menjelaskan bahwa pada saat seseorang melakukan pemaknaan, terdapat hirarki makna yang mampu membantu seseorang memberikan pemaknaan terhadap situasi komunikasi dan pesan yang dikirimkan oleh orang lain serta bagaimana memutuskan cara bertindak terhadap situasi tersebut (Littlejohn \& Foss, 2009).

Pola hirarkis tersebut dapat dilihat dalam gambar di bawah ini: 


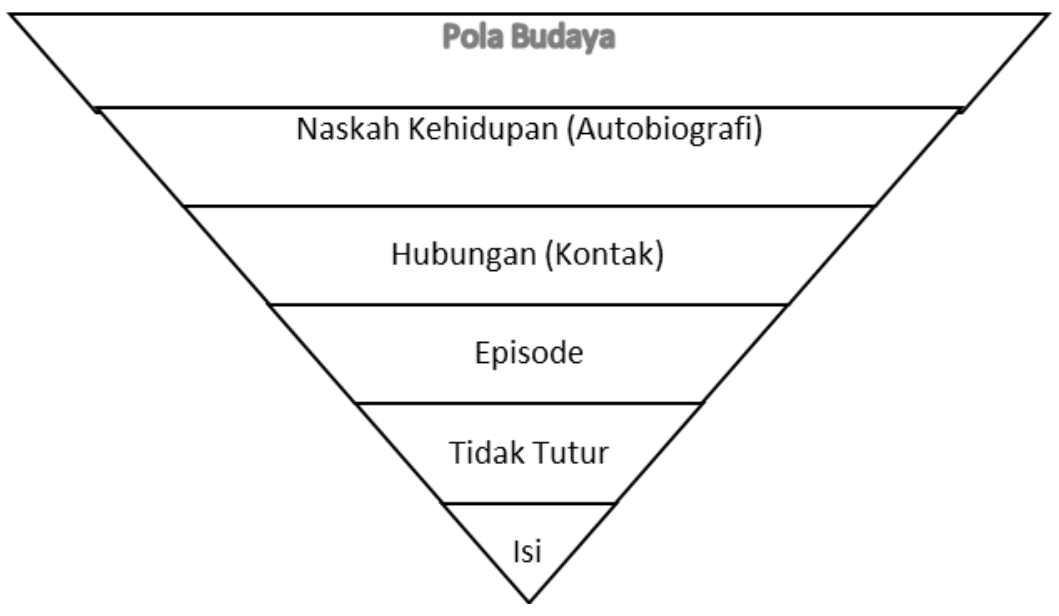

Gambar 1. Pola Hirarki Makna

Teori CMM mengemukakan enam level makna yakni isi, tindak tutur, episode, hubungan, naskah kehidupan, dan pola budaya sebagai berikut:

(1)Level Isi (content): merupakan langkah awal yang mana data mentah dikonversi menjadi makna. Menurut Wood (2004) isi merupakan sebuah konten komunikasi level terendah dalam hirarki makna. Isi merupakan kata-kata atau kalimat yang belum memiliki makna. Untuk mengkonstruksi makna daripada isi tersebut, kita harus mengacu pada level yang lebih tinggi dalam hirarki makna.

(2) Tindak Tutur (speech acts): Pearce (1994) mendeskripsikan tindak tutur sebagai tindakan-tindakan yang kita lakukan dengan cara berbicara, sebagai contoh adalah memuji, menghina, berjanji, mengancam, menyatakan, dan bertanya. Tindak tutur memberikan sebuah konteks untuk menginterpretasikan data mentah dari sebuah komunikasi (Wood, 2004).

(3) Episode: menurut Pearce dan Cronen (1980) mendefinisikan episode sebagai rutinitas komunikasi yang memiliki awal, pertengahan, dan akhir yang jelas. Episode mendeskripsikan konteks dimana orang bertindak. Pada level ini kita mulai melihat pengaruh dari konteks terhadap makna. Dalam sebuah interaksi, individu-individu mungkin akan memiliki perbedaan dalam bagaimana mereka "menandai" (punctuate) atau menekankan sebuah episode.

(4) Hubungan (relationship): pada level ini menggambarkan dimana dua orang menyadari potensi dan batasan mereka sebagai mitra dalam sebuah hubungan. Hubungan dapat dikatakan sebagai kontrak dimana terdapat tuntutan dalam berperilaku..

(5) Naskah Kehidupan (life scripts): merupakan kelompok-kelompok episode masa lalu atau masa kini yang menciptakan suatu sistem makna yang dapat dikelola bersama dengan orang lain. Kehidupan kita di masa lalu menentukan bagaimana kita berkomunikasi dengan orang lain.

(6) Pola Budaya: Pearce (1989) menyatakan bahwa manusia mengidentifikasi diri mereka dengan kelompok tertentu. Setiap diri kita berperilaku sesuai dengan nilai-nilai yang ada dalam masyarakat kita. Nilai tesebut terkait dengan jenis kelamin, ras, kelas, dan identitas religius.

\section{METODE}

Penelitian ini menggunakan paradigma konstrukstivisme. Paradigma ini meyakini bahwa individu-individu selalu berusaha untuk memahami dunia di mana mereka hidup dan bekerja melalui pemaknaan subyektif atas pengalaman-pengalaman mereka (Creswell, 2010).

Metode yang digunakan adalah kualitatif dengan pendekatan studi kasus yaitu diseminasi Pupuk Organik Hayati (POH) Beyonic Startmik-LIPI. Penelitian ini menganalisa tentang konstruksi makna komunikasi sains oleh peneliti dan humas melalui percakapan yang terjadi pada saat mereka mendiskusikan persiapan kegiatan diseminasi hasil riset POH Beyonic Startmik, pengkoordinasian pelaksanaan diseminasi, serta koordinasi dalam hal penyusunan konten-konten kehumasan.

Penelitian ini dilakukan pada bulan Februari-Mei 2021. Obyek dari penelitian ini adalah dialog atau percakapan yang terjadi antara peneliti dengan humas, bagaimana masing-masing komunikator sains tersebut menyampaikan dan memaknai pesan pada saat mereka melakukan kegiatan diseminasi POH BeyonicStartmik. Subyek atau informan dalam penelitian ini adalah peneliti POH Beyonic-Startmik dan humas LIPI. 
Penentuan informan dilakukan secara sengaja (purposive) yaitu staf Peneliti POH Beyonic Startmik-LIPI, Humas Pusat, serta Koordinator Humas Kawasan Cibinong. Penelitian ini menggunakan data primer dan sekunder. Data primer diperoleh percakapan peneliti dan humas melalui media whatsapp. Data primer juga diperoleh melalui wawancara terstruktur dengan staf Peneliti POH Beyonic Startmik-LIPI, staf Humas Pusat, serta Koordinator Humas Kawasan Cibinong. Sedangkan data sekunder diperoleh dari laporan hasil kegiatan diseminasi POH Beyonic Startmik LIPI, serta pemberitaan di website.

Teknik Analisa data dilakukan menggunakan tiga tahapan yaitu kondensasi, penyajian data, dan penarikan kesimpulan serta verifikasi. Proses kondensasi dilakukan melalui dua tahapan koding data, yaitu pengkodingan data hasil observasi di lapangan kemudian dilanjutkan pengkodingan kedua atau proses pengkategorisasian data. Proses penyajian data dalam penelitian ini menggunakan Software Atlas.ti guna memvisualisasikan temuan dalam penelitian. Setelah data disajikan kemudian dilakukan penarikan kesimpulan dan verifikasi berdasarkan rumusan masalah yang terdapat dalam penelitian ini.

Validitas data dalam penelitian ini dilakukan menggunakan triangulasi sumber yaitu dengan menganalisa percakapan antara Peneliti POH Beyonic Startmik-LIPI dengan Sekretaris Utama LIPI, serta percakapan antara Peneliti POH Beyonic Startmik-LIPI dengan Kepala Biro Kerjasama Hukum dan Humas LIPI.

\section{HASIL DAN PEMBAHASAN}

\section{Sekilas Tentang Diseminasi Hasil Penelitian POH Beyonic Startmik}

Kegiatan diseminasi hasil-hasil penelitian merupakan bentuk komunikasi sains yang dilakukan oleh LIPI sebagai lembaga riset terbesar dan tertua di Indonesia kepada masyarakat. Selain memperkenalkan hasil-hasil penelitian unggulan, kegiatan ini juga bertujuan untuk sharing knowledge tentang hasil-hasil penelitian yang dihasilkan oleh peneliti LIPI. Diseminasi hasil penelitian yang dilakukan oleh LIPI diharapkan mampu menciptakan kemandirian masyarakat daerah melalui pemanfaatan ilmu pengetahuan.

Salah satu hasil penelitian yang hingga kini masih banyak diminati oleh masyarakat adalah Pupuk Organic Hayati (POH) Beyonic Startmik. Kegiatan diseminasi POH Beyonic Startmik merupakan bentuk kerjasama antara LIPI dengan Komisi VII DPR RI sebagai mitra kerja LIPI di jajaran pemerintahan. Salah satu tujuan kegiatan diseminasi $\mathrm{POH}$ adalah untuk meningkatkan daya saing masyarakat melalui penguatan sektor pertanian. Hal tersebut sesuai dengan rencana Pembangunan Jangka Panjang Menengah (RPJM) yaitu peningkatan daya saing sumber daya alam berbasis iptek.

Diseminasi POH Beyonic Startmik merupakan bentuk pemanfaatan dan penerapan ilmu pengetahuan dan teknologi kepada masyarakat. Selain meningkatkan produktifitas petani, pengadopsian POH Hayati Startmik juga mendorong pembangunan pertanian berkelanjutan. Kehadiran POH Beyonic Startmik mendorong petani untuk beralih meninggalkan penggunaan pupuk kimia karena dapat merusak tanah dan lahan pertanian dalam jangka lama. $\mathrm{POH}$ Beyonic Startmik mampu mengembalikan peran tanah sebagai pondasi utama dalam kegiatan bertani dengan mengoptimalkan mikroba penyubur tanah dan hormon pemacu pertumbuhan. Pupuk cair ini juga mendorong kemandirian serta pemberdayaan petani karena terbuat dari bahan-bahan murah dan mudah didapatkan. Formula bahan dasar pupuk ini adalah sumber karbohidrat terdiri dari gula, tetes tebu, dan tepung jagung atau tapioka. Sementara sumber protein terdiri atas telur, kaldu daging, tepung ikan, tepung kedelai, kecambah yang ditambah dengan bahan agar-agar dan air kelapa.

Secara organisasi, diseminasi POH Beyonic Startmik merupakan bentuk sinergi antara LIPI selaku penyedia sumber inovasi, DPR RI berperan dalam pendanaan dan juga masyarakat (gapoktan) di daerah pemilihan (dapil) yang memiliki potensi alam namun masih memiliki produktivitas rendah sehingga perlu dihadirkan inovasi POH Beyonic Startmik.

Hingga kini, POH Beyonic Startmik telah didiseminasikan di berbagai daerah Indonesia serta diadopsi oleh ribuan petani dan industri. selain itu, melalui kegiatan diseminasi POH Beyonic Startmik, banyak kepala daerah yang mengajukan kerja sama dengan LIPI terkait dengan pembinaan petani pada tiap-tiap kecamatan dalam rangka meningkatkan produktivitas hasil panen. POH Beyonic Startmik merupakan salah satu hasil penelitian di LIPI yang telah memiliki hak paten dengan nomor paten P00201601284.

\section{Profil Aktor dan Level Komunikasi}

Berdasarkan data hasil penelitian, terdapat dua level percakapan yang terjadi pada proses pengkoordinasian kegiatan diseminasi POH Beyonic Startmik. Level pertama adalah percakapan yang terjadi antara Peneliti POH Beyonic Startmik dengan Humas LIPI Pusat. Level yang kedua adalah percakapan antara Peneliti POH 
Beyonic Startmik dengan Koordinator Humas LIPI Kawasan Cibinong. Masing-masing level memiliki tema percakapan yang berbeda. Level percakapan pertama membahas tentang koordinasi persiapan dan perencanaan teknis pelaksananaan diseminasi POH Beyonic Startmik di Pekalongan, Jawa Tengah. Level percakapan kedua membahas tentang koordinasi pembuatan konten kehumasan POH Beyonic Startmik berupa pembuatan feature berita di website serta proses edit text narasi video $\mathrm{POH}$ Beyonic Startmik berbahasa Inggris.

Aktor-aktor komunikasi yang terlibat dalam kegiatan diseminasi POH Beyonic Startmik LIPI di antaranya Peneliti POH Beyonic Startmik, Staf Humas LIPI Pusat, serta Koordinator Humas LIPI Kawasan Cibinong. Secara struktur organisasi, para aktor yang terlibat dalam kegiatan diseminasi POH Beyonic Startmik berasal dari dua satuan kerja (satker) yang berbeda. Peneliti POH Beyonic Startmik bekerja di bawah Pusat Penelitian Biologi (P2 Biologi) LIPI, sedangkan Humas Pusat dan Koordinator Humas Kawasan Cibinong berada di bawah Biro Kerjasama Hukum dan Humas (BKHH) LIPI. Oleh karena itu, kegiatan diseminasi POH Beyonic Startmik merupakan kegiatan lintas sektoral yang melibatkan dua satuan kerja berbeda di LIPI. Ditinjau dari peran dan fungsinya, masing-masing aktor tersebut memiliki peran dan tugas berbeda sehingga dibutuhkan pengkoordinasian pesan dalam bentuk percakapan agar komunikasi dapat berjalan dengan efektif.

Aktor pertama yaitu peneliti POH Beyonic Startmik berperan sebagai narasumber yang menyampaikan hasil riset POH Beyonic Startmik kepada peserta diseminasi. Selain itu, peneliti POH Beyonic Startmik juga berkoordinasi dengan tim teknisi guna memastikan alat dan bahan yang digunakan pada saat presentasi. Terkait dengan fungsi manajerial dalam organisasi, peneliti $\mathrm{POH}$ Beyonic Startmik dalam hal ini juga bertindak sebagai aktor yang memiliki wewenang untuk menentukan narasumber pengganti, pada saat pelaksanaan diseminasi.

Aktor kedua yaitu staf humas pusat dengan jabatan fungsional Pranata Humas Madya. Saat penelitian ini dimulai, staf humas pusat berada di bawah koordinasi Kepala Bagian Humas dan Informasi Publik yang berada di Kantor LIPI Jakarta. Kini nomenklatur tersebut berubah menjadi Koordinator Fungsi Layanan Humas dan Protokol. Dalam kaitannya dengan kegiatan diseminasi POH Beyonic Startmik, staf humas Pusat berperan sebagai Liaison Officer (LO) atau penghubung antara LIPI dengan Anggota DPR RI Komisi VII untuk berkomunikasi dan berkordinasi terkait dengan permintaan diseminasi hasil riset LIPI. Penunjunkan sebagai LO ditetapkan secara resmi oleh sekretariat DPR dan dibuktikan dengan adanya surat tugas. LIPI dalam penelitian ini dimaknai dengan level pimpinan dan level teknis. Pada level pimpinan, Humas Pusat berkoodinasi dengan Kepala LIPI dan Sekretaris Utama LIPI terkait dengan permintaan kegiatan diseminasi hasil-hasil riset LIPI, sedangkan di level teknis Humas Pusat berkoordinasi dengan Peneliti POH Beyonic Startmik dan tim terkait dengan penyampaian jadwal, lokasi, persiapan-persiapan, serta hal-hal teknis yang berhubungan dengan pelaksanaan diseminasi di lapangan.

Aktor yang ketiga adalah Koordinator Humas Kawasan Cibinong. Koordinator Humas Kawasan Cibinong dalam kesehariannya bertugas sebagai penyedia layanan kerja sama dan humas di Kawasan Multi Satker Cibinong (Cibinong Science Center) dan humas bagi empat multisatker yaitu Pusat Penelitian (Puslit) Biologi, Puslit Biomaterial, Puslit Bioteknologi, Puslit Limnologi, dan satu satuan kerja tunggal Pusat Pembinaan Pendidikan dan Pelatihan Peneliti (Pusbindiklat). Dalam konteks penelitian ini, Koordinator Humas Kawasan Cibinong berkoordinasi dengan peneliti POH Beyonic Startmik dalam rangka penyusunan konten kehumasan melalui kanal website korporat.

\section{Strategi Komunikasi Humas dan Peneliti}

Setiap lembaga penelitian dan pengembangan tentu saja memiliki strategi komunikasi yang berbeda dalam mendiseminasikan hasil riset kepada masyarakat. Strategi komunikasi tersebut mencakup level manajerial, level kelompok, hingga level antar individu. Dalam penelitian ini, strategi yang dimaksud adalah strategi komunikasi yang dilakukan oleh Peneliti dengan Humas pada saat melakukan koordinasi terkait dengan kegiatan diseminasi POH Beyoni Startmik LIPI. Strategi komunikasi dalam penelitian ini dimaksudkan pengkoordinasian pesan dalam tahapan komunikasi yang dilakukan oleh Peneliti dan Humas. Tujuan dari strategi komunikasi yang dilakukan oleh Peneliti dan Humas adalah agar kegiatan diseminasi pembuatan POH Beyonic Startmik kepada masyarakat berjalan dengan efektif dan lancar.

Berikut disajikan tabel hirarki makna yang merupakan hasil penelitian dari dua bagian percakapan. Percakapan dalam tabel bagian 1 adalah sajian data analisis percakapan antara Peneliti Biologi LIPI yang meneliti POH Beyonic Startmik dengan Staf Humas LIPI. Selanjutnya, dalam tabel bagian 2 adalah sajian 
data analisis percakapan antara Peneliti Biologi yang meneliti POH Beyonic Startmik dengan Koordinator Humas Kawasan Cibinong.

Tabel 1. Hirarki makna percakapan antara Peneliti POH Beyonic Stratmik dengan Humas Pusat

\begin{tabular}{|c|c|c|c|c|c|c|}
\hline \multirow{2}{*}{ Aktor } & \multicolumn{6}{|c|}{ Hirarki Makna } \\
\hline & Isi & Tindak tutur & Episode & Hubungan & $\begin{array}{c}\text { Naskah } \\
\text { kehidupan }\end{array}$ & Pola budaya \\
\hline \multirow[t]{2}{*}{$\begin{array}{l}\text { Peneliti } \\
\text { POH }\end{array}$} & $\begin{array}{l}\text { Pelaksanaan } \\
\text { diseminasi }\end{array}$ & $\begin{array}{l}\text { 1. Menanyakan } \\
\text { 2. Mengarahkan }\end{array}$ & $\begin{array}{l}\text { Penginformasian } \\
\text { permintaan } \\
\text { diseminasi }\end{array}$ & Akrab & $\begin{array}{l}\text { Kebanggaan } \\
\text { diri }\end{array}$ & Melayani \\
\hline & $\begin{array}{l}\text { Pelaksanaan } \\
\text { diseminasi }\end{array}$ & $\begin{array}{l}\text { 1. Menanyakan } \\
\text { 2. Berkeluh-kesah }\end{array}$ & $\begin{array}{l}\text { Konfirmasi } \\
\text { kehadiran sebagai } \\
\text { narasumber }\end{array}$ & Akrab & $\begin{array}{l}\text { POH inovasi } \\
\text { unggulan di } \\
\text { LIPI }\end{array}$ & Melayani \\
\hline \multirow[t]{2}{*}{$\begin{array}{l}\text { Humas } \\
\text { Pusat }\end{array}$} & $\begin{array}{l}\text { Pelaksanaan } \\
\text { diseminasi }\end{array}$ & Menginformasikan & $\begin{array}{l}\text { Penginformasian } \\
\text { permintaan } \\
\text { diseminasi }\end{array}$ & Hormat & $\begin{array}{l}\text { Pengalaman } \\
\text { berorganisasi }\end{array}$ & Melayani \\
\hline & $\begin{array}{l}\text { Pelaksanaan } \\
\text { diseminasi }\end{array}$ & Menginformasikan & $\begin{array}{l}\text { Konfirmasi } \\
\text { kehadiran sebagai } \\
\text { narasumber }\end{array}$ & $\begin{array}{l}\text { Perhatian } \\
\text { Akrab }\end{array}$ & $\begin{array}{l}\text { Pengalaman } \\
\text { berorganisasi }\end{array}$ & Melayani \\
\hline
\end{tabular}

Sumber: olah data hasil percakapan Peneliti POH Beyonic Startmik dengan Peneliti Pusat

Tabel 1. Hirarki makna percakapan antara Peneliti POH Beyonic Stratmik dengan Koordinator Humas Kawasan Cibinong

\begin{tabular}{|c|c|c|c|c|c|c|}
\hline \multirow{2}{*}{ Aktor } & \multicolumn{6}{|c|}{ Hirarki Makna } \\
\hline & Isi & Tindak tutur & Episode & Hubungan & $\begin{array}{c}\text { Naskah } \\
\text { kehidupan }\end{array}$ & Pola budaya \\
\hline \multirow[t]{2}{*}{$\begin{array}{l}\text { Peneliti } \\
\text { POH }\end{array}$} & $\begin{array}{l}\text { Bahan berita } \\
\text { Proses edit }\end{array}$ & Mengarahkan & $\begin{array}{l}\text { Penyusunan } \\
\text { konten berita }\end{array}$ & Akrab & $\begin{array}{l}\text { Membangga } \\
\text { kan diri }\end{array}$ & Melayani \\
\hline & $\begin{array}{l}\text { Eksistensi } \\
\mathrm{POH}\end{array}$ & $\begin{array}{l}\text { Membanggakan } \\
\text { kinerja }\end{array}$ & $\begin{array}{l}\text { Penyusunan } \\
\text { konten berita }\end{array}$ & Percaya & $\begin{array}{l}\mathrm{POH} \\
\text { inovasi } \\
\text { unggulan } \\
\text { LIPI }\end{array}$ & Melayani \\
\hline \multirow[t]{2}{*}{$\begin{array}{l}\text { Humas } \\
\text { Cibinong }\end{array}$} & $\begin{array}{l}\text { Bahan berita } \\
\text { Proses edit }\end{array}$ & $\begin{array}{l}\text { Bertanya dan } \\
\text { meminta } \\
\text { Menindaklanjuti }\end{array}$ & $\begin{array}{l}\text { Penyusunan } \\
\text { konten berita }\end{array}$ & Hormat & Melayani & Melayani \\
\hline & $\begin{array}{l}\text { Eksistensi } \\
\mathrm{POH}\end{array}$ & $\begin{array}{l}\text { Mengadvokasi } \\
\text { empati }\end{array}$ & $\begin{array}{l}\text { Tulisan } \\
\text { featrure }\end{array}$ & Akrab & Melayani & Melayani \\
\hline
\end{tabular}

Sumber: olah data hasil percakapan Peneliti POH Beyonic Startmik dengan Koordinator Humas Kawasan Cibinong

Berdasarkan tabel tersebut, penulis mengkategorikan strategi komunikasi yang dilakukan oleh Humas dan Peneliti dalam kegiatan diseminasi POH Beyonic Startmik ke dalam tiga tahapan antara lain: tahap perencanaan, tahap pelaksanaan, serta tahap evaluasi. Berikut penulis berikan penjelasan tentang tahapantahapan tersebut:

\section{Tahap Perencanaan}

Pada tahap ini terdapat dua tema pengkoordinasian yang dilakukan oleh Peneliti POH Beyonic Startmik dengan Humas Pusat. Tema tersebut antara lain terkait dengan persiapan dan kesiapan. 


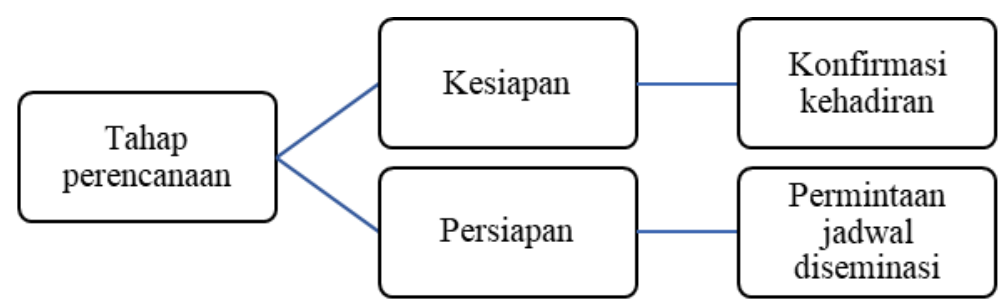

Gambar 2. Strategi Komunikasi Pada Tahap Perencanaan

Sumber: Hasil olah data percakapan antara Humas Pusat dengan Peneliti POH Beyonic Startmik

Berdasarkan hasil olah data pada percakapan antara Peneliti POH Beyonic Startmik dengan Humas Pusat pada saat berkoordinasi di tahap perencanaan, terdapat dua tema pembicaraan utama yang mendasari kedua aktor tersebut melakukan percakapan yaitu tema kesiapan dan persiapan. Berdasarkan hirarki makna yang terdapat dalam teori manajemen makna terkoordinasi (CMM), tema kesiapan dan persiapan termasuk ke dalam kategori level isi. Dalam hirarki makna, Isi merupakan langkah awal seseorang mengkonversi data menjadi makna. Kesiapan dan persiapan dalam hal ini dimaknai oleh Peneliti POH Beyonic Startmik dan Humas Pusat sebagai inti topik pembicaraan yang harus dikoordinasikan dalam tahap perencanaan diseminasi. Menurut Wood (2004) isi merupakan sebuah konten komunikasi level terendah dalam hirarki makna.

Pada saat Peneliti POH Beyonic Startmik dan Humas Pusat berkoordinasi tentang tema kesiapan terdapat episode percakapan yang memberikan konteks dimana kedua aktor tersebut berkoordinasi. Episode tersebut terjadi pada saat Peneliti POH Beyonic Startmik dan Humas Pusat melakukan percakapan tentang konfirmasi kehadiran sebagai narasumber. Dalam teori CMM disebutkan bahwa level episode dimaksud sebagai rutinitas komunikasi yang memiliki awal, pertengahan, dan akhir yang jelas. Dalam konteks penelitian ini, kronologi episode konfirmasi kehadiran sebagai narasumber diawali dengan informasi jadwal diseminasi yang telah Humas Pusat dapatkan dari anggota Komisi VII DPR RI. Setelah mendapatkan jadwal diseminasi, kemudian Humas mengkoordinasikan dengan Peneliti terkait dengan permintaan diseminasi tersebut serta kesediaan hadir di lokasi. Pengkoordinasian jadwal diseminasi antara Peneliti dan Humas penting dilakukan karena terkait dengan kesediaan Peneliti untuk mengisi pelatihan pembuatan POH Beyonic Startmik pada tanggal yang sudah ditentukan. Berikut percakapan antara Humas Pusat dengan Peneliti POH Beyonic Startmik terkait pengkoordinasian pada episode konfirmasi kehadiran sebagai narasumber:

Humas: "Perubahan lokasi Pak Anton, semula Pemalang pindah Pekalongan, utk tgl tetap 20 Maret. Mdh2an Pak Anton bisa hadir di lokasi. Tks."

Peneliti: "Hallo Pak Yusuar, semoga selalu dalam kondisi Prima! Soal kehadiran di lokasi dalam pelatihan... ini kami2x kan termasuk yg beresiko tinggi terkait USIA dan COVID, jadi saya kira harus memperhatikan hal tersebut, Untuk pelaksanaan, sudah dan sedang diurus dengan tim PPII"

Berdasarkan percakapan di atas maka pada saat Humas Pusat mengkoordinasikan isi pesan terkait dengan kehadiran narasumber di lokasi, Humas Pusat bertindak tutur dengan mengkonfirmasi pesan tersebut kepada Peneliti POH Beyonic Startmik. Kemudian Peneliti merespon permintaan kehadiran sebagai narasumber di lokasi dengan tindak tutur meminta untuk dipertimbangkan. Respon tersebut disampaikan oleh Peneliti karena terkait dengan usia nya yang rentan terpapar virus covid-19 apabila hadir di lokasi. Peneliti menyadari pada masa pandemi seperti sekarang ini, keselamatan jiwa merupakan faktor utama terpenting dalam setiap kegiatan.

Kaitannya dengan asumsi kedua dari teori ini, disebutkan bahwa manusia saling menciptakan realitas sosial. Pada saat berkoordinasi tentang episode permintaan kehadiran sebagai narasumber di lokasi, kedua aktor memiliki pengalaman episode-episode percakapan dimasa lalu yang memunculkan realitas-realitas sosial sebelumnya. Dalam hal ini, pengalaman percakapan sebelumnya tentang bahaya virus covid-19 mempengaruhi realitas sosial Peneliti POH yang pada akhirnya turut menentukan realitas sosial baru yang terjadi pada saat melakukan percakapan dengan Humas Pusat. Dalam hal ini Peneliti POH Beyonic menginginkan agar metode penyampaian materi dilakukan secara online.

Pada tema persiapan, terdapat episode percakapan antara Peneliti POH Beyonic Startmik dengan Humas Pusat yang membicarakan tentang permintaan jadwal diseminasi. Berikut disajikan percakapan yang mendukung pernyataan sebelumnya: 
Humas Pusat: $\quad$ Pak Anton, ini sdh ada lagi permintaan diseminasi dari Anggota DPR utk bulan Maret. Tks.

Peneliti POH: $\quad$ Baik Pak Yusuar .... perlu dipersiapkan dg lebih baik ... oh iya bukan nagih ya... kalau tidak salah ketika kita ngisi narasumber juga ada uang lelah-nya (?), seperti beberapa waktu lalu ketika ngisi acara pembekalan para purnabakti, saya ngisi narsum secara online ... mungkin bisa sebagai pengganti quota internet... dan yang jelas karena memang ada pagu anggarannya mestinya?

Peneliti POH: tks.

Humas Pusat: baik Pak Anton.

Berdasarkan percakapan di atas, pada saat Humas Pusat melakukan koordinasi terkait permintaan jadwal diseminasi maka masing-masing memiliki pengalaman percakapan yang didapatkan dari realitas sosial sebelumnya. Hal tersebut sesuai dengan asumsi kedua yang terdapat dalam teori CMM yang menyatakan bahwa manusia saling menciptakan realitas sosial. Pada episode permintaan jadwal diseminasi di atas, ketika Humas Pusat menyampaikan informasi kepada Peneliti POH tentang adanya permintaan diseminasi maka Humas Pusat membawa pengalaman percakapan yang didapatkan dari realitas sosial yang tercipta pada saat berdialog dengan anggota DPR. Pada sisi yang lain, pengalaman percakapan yang dialami oleh Peneliti POH melalui interaksi sosial sebelumnya pada saat Peneliti POH menjadi narasumber di acara pembekalan purnabakti kemudian Peneliti POH bertindak tutur dengan mengkonfirmasi masalah honor sebagai narasumber. Kemudian Humas Pusat merespon dengan tindak tutur "baik Pak Anton" yang dimaknai sebagai Humas Pusat menyadari kemudian menyetujui atau membenarkan apa yang Peneliti POH sampaikan.

Dalam hal ini, sesuai dengan asumsi ketiga dari teori ini yaitu bagaimana orang mengendalikan percakapan melalui transaksi informasi yang dipengaruhi oleh makna pribadi dan makna antarpribadi. Makna pribadi merupakan pengalaman-pengalaman unik yang dibawa Humas Pusat dan Peneliti POH pada saat mereka berdialog sedangkan makna antar pribadi merupakan makna yang tercapai pada saat kedua orang tersebut sepakat dengan penafsiran tentang sebuah makna. Semakin banyak makna antarpribadi tercapai maka tingkat keberhasilan transaksi informasi akan semakin tinggi sehingga bisa dikatakan komunikasi berjalan dengan efektif.

\section{Tahap Pelaksanaan}

Pada tahap ini, pengkoordinasian pesan antara Humas dan Peneliti dilakukan dengan mengkoordinasikan tema persiapan perjalanan dan metode presentasi. Pada tema pembicaraan persiapan perjalanan, peneliti dan humas saling berkoordinasi terkait pembekalan tim, kewajiban tim untuk mematuhi protokol kesehatan pada masa pandemi, serta metode pemaparan. Berikut percakapan peneliti dan humas terkait dengan pengkoordinasian substansi persiapan perjalanan serta metode pemaparan:

Humas: "Pak Anton terkait pelaksanaan di pekalongan, Bapak bisa hadir kan sebagai narasumber?"

Peneliti: "Pak Entis yang akan jalan silahkan mewakili. intinya karena p Entis kan mewakili team $\mathrm{POH}$, jadi jangan ragu untuk disuarakan inovasi $\mathrm{POH}$ merupakan kegiatan kita (Kegiatan Mikrobiologi Pertanian, Keltian Fisiologi-P2Biologi LIPI). Jangan lupa minta rapid test berangkat (untuk meyakinkan daerah kalau kita tidak bawa penularan COVID) dan swab test waktu pulang karena juga punya tugas di lab.. jadi tidk perlu karantina mandiri, kalau sudah tahu bebas Covid dari swab test. "Kalau bisa diusahan pemaparan pembekalan bisa pakai ZOOM itu akan bagus sekali bisa juga mengenalkan teknologi ke daerah, ya team BKHH harus ada eford supaya bisa zoom, tks.".

Berdasarkan percakapan di atas maka dapat dijelaskan bahwa meskipun di masa pandemi akan tetapi kegiatan diseminasi harus tetap dilaksanakan meskipun secara daring. Kaitanya dengan teori ini, bahwa pada level naskah kehidupan yang dimiliki oleh Peneliti serta Humas mendorong mereka untuk tetap memberikan ilmu pengetahuan kepada masyarakat dalam kondisi apapun. Dalam teori CMM naskah kehidupan merupakan kelompok-kelompok episode masa lalu atau masa kini yang menciptakan suatu sistem makna yang dapat dikelola bersama dengan orang lain.

Berdasarkan hasil penelitian disebutkan bahwa naskah kehidupan Peneliti dipengaruhi oleh kebanggaan diri Peneliti atas penemuan $\mathrm{POH}$ Beyonic Startmik yang membantu dalam meningkatkan produktivitas 
masyarakat dan telah diadopsi oleh pemerintah daerah maupun ribuan petani di Indonesia. Kebanggan diri yang dirasakan oleh Peneliti berikutnya adalah POH Beyonic Startmik merupakan salah satu hasil penelitian paling berhasil di LIPI dan sudah mendapatkan hak paten serta royalti. Berikut hasil wawancara Humas Pusat terkait dengan pernyataan tersebut:

"pada intinya sih dari sisi Pak Anton sebagai peneliti, dia senang kalau dia bawa hasil penelitiannya itu bisa bermanfaat pada masyarakat gitu ya. Tapi di sisi lain dia selektif juga artinya di masa pandemic ini, dia tidak mau.. tidak mau.. artinya hanya didiseminasikan saja tapi tidak menambah ilmu untuk masyarakatnya, makanya jadinya dia tetep ingin ngotot harus ada paparan dari beliau, menyampaikan apa sih yang Namanya POH itu apa gitu, jadi dia tidak terima gitu saja, ok diseminasi ok silahkan enggak.. tapi dia ingin menyampaikan sharing ilmu"

Level naskah kehidupan dalam hirarki makna pada teori manajemen makna terkoordinasi menjelaskan bahwa naskah kehidupan merupakan episode-episode masa lalu yang dimiliki oleh seseorang yang dapat menentukan bagaimana kita berkomunikasi saat ini (Nurhaipah, 2019). Berdasarkan naskah kehidupan yang dimiliki oleh seseorang, maka mampu menentukan level pola budaya seseorang tersebut.

Pola budaya merupakan level tertinggi dalam hirarki makna yang dimiliki oleh seseorang. Pearce (1989) menyatakan bahwa manusia mengidentifikasi diri mereka dengan kelompok tertentu. Setiap diri kita berperilaku sesuai dengan nilai-nilai yang ada dalam masyarakat kita. Nilai tesebut terkait dengan jenis kelamin, ras, kelas, dan identitas religius. Dalam hal ini pola budaya yang dimiliki oleh Peneliti dan Humas adalah melayani. Komunikasi sains yang dilakukan oleh Peneliti dan Humas LIPI didasari atas sikap melayani kepada masyarakat. Mereka telah mencapai pada puncak pemaknaan tentang komunikasi sains yaitu budaya melayani masyarakat sebagai sektor pengguna hasil-hasil penelitian. Peneliti dan Humas menyadari bahwa hasil riset harus didiseminasikan supaya bermanfaat bagi masyarakat.

\section{Tahap Evaluasi}

Strategi komunikasi yang dilakukan humas dan peneliti pada tahap evaluasi adalah dengan mengkoordinasikan proses penyusunan konten kehumasan tentang $\mathrm{POH}$ Beyonic Startmik. Pada tahap penyusunan konten kehumasan, terdapat dua substansi pengkoordinasian makna antara humas dengan peneliti. yaitu substansi pengeditan teks bahasa Inggris pada media video dan youtube. Substansi kedua adalah penyusunan bahan pemberitaan $\mathrm{POH}$ Beyonic Startmik di website P2 Biologi LIPI. Berikut percakapan antara Koordinator Humas Cibinong dengan Peneliti POH Beyonic Startmik terkait dengan strategi komunikasi dalam penyusunan konten kehumasan.

Humas: "Pagi Bapak? Izin Bapak mau tanya, apakah bapak memiliki video terkait POH nya Pak? Ini diminta Kepala BKHH, Mba Mila untuk menambahkan materi/konten video untuk pameran Expo 2021 Dubai"

Peneliti: "Ada yg dulu dibuat BIT, sayangnya dalam bhs Indonesia, sebetulnya saya sudah buat running textnya dalam.bhs Indonesia tapi belum di edit ke vedionya pak. ini saya ada running teksnya tinggal masukkan/edit"

Humas: "monggo pak nanti saya sampaikan biar diedit humas pusat"

Peneliti: "Kalau yang ini belum, kalau BKHH bisa bantu akan sangat berterima kasih kami... sebetulnya banyak kawan dari Asing yg berminat"

Berdasarkan percakapan di atas, terlihat bagaimana hubungan akrab yang terbangun antara humas dengan peneliti. Berdasarkan hirarki makna dalam teori CMM terdapat level hubungan. Level hubungan menggambarkan dimana dua orang menyadari potensi dan batasan mereka sebagai mitra dalam sebuah hubungan. Dalam percakapan tersebut dapat terlihat bahwa kedua aktor saling menyadari potensi serta batasan masing-masing. Koordinator Humas Kawasan Bogor menyadari akan keterbatasan informasi tentang POH Beyonic Startmik sedangkan kan pada sisi yang lain, Peneliti POH menyadari keterbatasan nya dalam mengedit naskah ke dalam video. Kedua aktor tersebut terlibat ke dalam sebuah hubungan dimana terdapat tuntutan dalam berperilaku.

Berdasarkan sifat hubungan yang terjadi antara Peneliti POH Beyonic Startmik dengan Koordinator Humas Kawasan Cibinong maka terdapat hubungan hormat. Berikut penulis sajikan percakapan antara Humas Y2 
dengan Peneliti $\mathrm{X}$ terkait dengan persiapan pembuatan feature berita tentang $\mathrm{POH}$ Beyonic Startmik tersebut:

Humas Y2: Rencana kita mau bikin feature ttg POH pak, biar Update lg beritanya, kira-kira bapak punya bahan sekilas PoH ini pak? Nanti tinggal tambah statement bapak terbaru. Kalau ada biar kita draftkan dulu dan nanti proof read bapak?

Peneliti X: Ya pak... kadang kita yg "dibawah" bingung permintaan diseminasi kan masih banyak.. tapi kebijakan pimpinan tentu kita tidak tahu ... kami sudah mempunyai POH spesifik unutk seralia, Singkong, pisang dan kacang $2 x$ an. Kalau POH yang sudah beredar kan fungsinya general.. dan sekarang projek yang sedang jalan $\mathrm{POH}$ unutk bawang dan $\mathrm{POH}$ unutk cabai... pendanaan juga murni dari mandatori Ristek-BRIN LPDP.. dari LIPI sendiri malah gak ada budgetnya.

Humas Y2: Iya pak, semua merasakan dampak reorganisasi, pandemi dan transisi lipi ke brin ini. Temen2 peneliti satker lain juga curcol senada ke saya.

Humas Y1: Biar nanti "nyelip" dikit kendala POH ini di tulisan featurenya

Peneliti X: Ya pak kita mencoba survive dengan berkarya semaksimal mungkin... cuma ya saya sampaikan kalau ada permintaan diseminasi tolong tulis saja ke pimpinan... dan kenyataanya dari Komisi 7 DPR masih terus meminta disminasi... tahun 2020 dikala pandemi aja tetap jalan di sekitar 10 Wilayah.

Berdasarkan percakapan di atas, tindak tutur Humas Y2 pada saat meminta bahan sekilas POH Beyonic Startmik dilakukan dengan gaya bahasa formal. Tindak tutur memberikan sebuah konteks untuk menginterpretasikan data mentah dari sebuah komunikasi (Wood, 2004). Tindak tutur merupakan konfigurasi dari logika makna dan tindakan dari percakapan, dan konfigurasi ini dibangun bersama. Ketika Humas Y2 bertindak tutur menggunakan gaya bahasa formal, hal tersebut dipengaruhi persepsi Humas Y2 terhadap Peneliti X sebagai peneliti senior di LIPI yang berhasil mengembangkan inovasi yang spektakuler, paling sering didiseminasikan, serta banyak diminati oleh masyarakat. Dalam teori CMM disebutkan bahwa pengkoordinasian sebuah makna dipengaruhi oleh persepsi, kenangan dan konsep seseorang terhadap makna pesan yang disampaikan oleh orang lain. Kaitannya dengan penelitian ini maka persepsi Humas Y2 tentang kompetensi serta kinerja Peneliti X mempengaruhi sifat hubungan yang dimiliki oleh Humas Y2 terhadap Peneliti X.

Pada sisi yang lain, meskipun dalam percakapan tersebut Peneliti X merespon dengan berkeluh-kesah terkait kebijakan pimpinan akan tetapi keluhan tersebut tetap disampaikan menggunakan tata bahasa dan tindak tutur yang formil. Hal tersebut dilakukan karena antara Peneliti X dengan Humas Y2 belum pernah mengenal serta terlibat dalam kegiatan diseminasi sebelumnya. Berbeda dengan pada saat Peneliti $\mathrm{X}$ berdialog dengan Humas Y1 yang terkesan akrab karena satu angkatan bekerja di LIPI jadi sudah mengenal satu sama lain sebelum kegiatan diseminasi berlangsung.

Dalam teori CMM juga disebutkan bahwa dalam level hubungan dikenal istilah "keterlibatan", merupakan tingkat batas dua orang mengidentifikasikan diri mereka sebagai bagian dari suatu sistem. Dalam konteks ini, sudah lebih dari dua tahun Humas Y1 dan Peneliti X terlibat dalam kegiatan diseminasi POH Beyonic Startmik. Berbagai realitas sosial melalui percakapan dalam mengkoordinasikan makna pesan telah banyak mereka lalui. Hal tersebut melatar belakangi hubungan yang terjadi antara Humas Y1 dengan Peneliti X berjalan dengan akrab. Berbeda dengan hubungan antara Peneliti X dengan Humas Y2 yang memiliki perbedaan usia serta belum pernah mengenal satu sama lain sehingga hubungan yang terbangun bersifat formil.

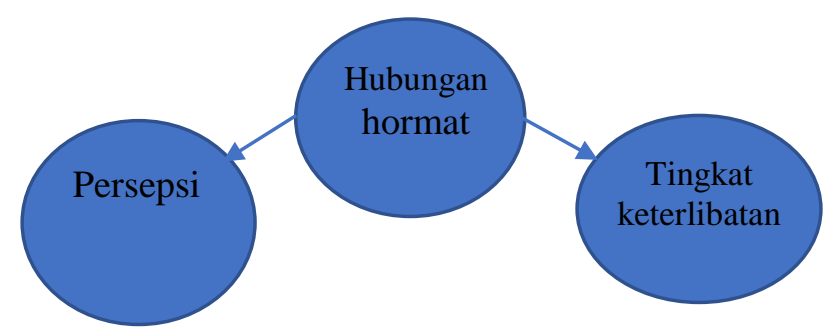

Gambar 3. Hubungan antara Peneliti X dengan Humas Y2.

\section{KESIMPULAN}

Jurnal Komunikasi Pembangunan | Vol. 19 (02) 2021| 107 
Strategi komunikasi yang dilakukan oleh Peneliti dan Humas LIPI dalam diseminasi POH Beyonic Startmik dilakukan dalam tiga tahap yaitu, tahap perencanaan, pelaksanaan dan evaluasi. Berdasarkan hasil pembahasan menggunakan enam hirarki makna yang terdapat dalam teori manajemen makna terkoordinasi, dapat disimpulkan bahwa Peneliti dan Humas memaknai level isi sebagai tema kesiapan dan persiapan yang terdapat dalam tahap perencanaan. Kesiapan dan persiapan merupakan unsur penting yang harus dikoordinasikan sebelum kegiatan diseminasi dilakukan. Pada tema tersebut terjadi pengkoordinasian tentang episode penginformasian permintaan jadwal diseminasi serta episode konfirmasi kehadiran sebagai narasumber. Dalam hal ini, pengkoordinasian sangat penting dilakukan oleh Peneliti dan Humas dalam rangka menyampaikan serta memaknai pesan untuk mencapai pemahaman dan kesepakatan satu sama lain sehingga kegiatan dapat berjalan dengan lancar.

Pada tahap pelaksanaan, level naskah kehidupan dan pola budaya merupakan elemen penting yang mempengaruhi Peneliti dan Humas. Naskah kehidupan yang dimiliki Peneliti dan Humas menentukan bagaimana mereka berkomunikasi pada saat ini. Naskah kehidupan Peneliti dalam penelitian ini adalah kebanggaan diri Peneliti terhadap kebermanfaatan POH Beyonic Startmik serta dijadikannya POH Beyonic Startmik sebagai salah satu inovasi unggulan LIPI. Naskah kehidupan tersebut mempengaruhi pola budaya Peneliti dan Humas sebagai seseorang yang berjiwa melayani. Dalam kegiatan diseminasi hasil penelitian, sikap melayani merupakan faktor penting yang harus dimiliki oleh aktor komunikasi sains untuk mendukung tingkat keberhasilan adopsi inovasi.

Pada tahap evaluasi, level tindak tutur dan hubungan mempengaruhi koordinasi antara Peneliti dengan Humas. Peneliti dan Humas memaknai hubungan dengan sebuah kontrak kerjasama saling membutuhkan satu sama lain sehingga tercipta sebuah hubungan saling percaya dan menghormati. Dalam konteks penelitian ini, hubungan kepercayaan yang dimiliki oleh aktor-aktor yang terlibat dalam komunikasi sains sangat lah penting. Masing-masing aktor saling menyadari potensi dan keterbatasan sehinga tercipta sebuah hubungan yang harmonis.

\section{DAFTAR PUSTAKA}

Adriyani, F. Y. (2019). Pemanfaatan Cyber Extention Sebagai Media Diseminasi Inovasi Pertanian Oleh Penyuluh Pertanian Di Provinsi Lampung ( Extension Agriculture's s Utilization of Cyber Extension as Dissemination Media for Agricultural Inovation in Lampung Province ). Journal of Extension and Development, 1(1), 1-7.

Antonius, S., Dwi Sahputra, R., Nuraini, Y., \& Kumala Dewi, T. (2018). Manfaat Pupuk Organik Hayati, Kompos dan Biochar pada Pertumbuhan Bawang Merah dan Pengaruhnya terhadap Biokimia Tanah Pada Percobaan Pot Menggunakan Tanah Ultisol. Jurnal Biologi Indonesia, 14(2), 234-250. https://doi.org/10.47349/jbi/14022018/243

Asngari, P. S. (2008). Pemberdayaan Manusia Pembangunan Yang Bermartabat. Pustaka Bangsa Press.

Astirin, O. P. (2018). Hilirisasi produk riset melalui kegiatan pengabdian kepada masyarakat*). Jurnal SNIEMAS, 1-5.

Autzen, C. (2014). Press releases — the new trend in science communication. 13(October 2012), 1-8.

Beidas, R. ., \& Kendall, P. . (2014). Dissemination and Implementation of Evidence-Based Practices in Child and Adolesenct Mental Health. Oxford University Press.

Creswell, J. W. (2010). Research Design Pendekatan Kualitatif, Kuantitatif, dan Mixed. Pustaka Pelajar.

Fauzi, A. M. (2008). Upaya Peningkatan Keamanan Mutu dan Gizi Pangan. IPB Press.

Fay, D. L. (2015). Strategi Diseminasi Farmer Managed Extension Activities (FMA) Sebagai Upaya Mewujudkan Petani Mandiri Dan Berdaya Di Kabupaten Temanggung. Komunikasi Pembangunan.

Gartina, D. (2015). Diseminasi Inovasi Teknologi Pertanian Melalui Portal Web Badan Penelitian Dan Pengembangan Pertanian. Jurnal Informatika Pertanian, 24(1), 121-132.

Gascoigne, T., \& Metcalfe, J. (2017). The emergence of modern science communication in Australia. Journal of Science Communication, 16(3), 1-18. https://doi.org/10.22323/2.16030201 
Hamzah, Idhan, A., \& Syamsia. (2019). Diseminasi Teknologi Pengelolaan Limbah Pertanian Menjadi. Jurnal Dedikasi Masyarakat, 2(2), 83-91.

Irawan, Dariah, A., \& Rachman, A. (2015). Pengembangan dan Diseminasi Inovasi Teknologi Pertanian Mendukung Optimalisasi Pengelolaan Lahan Kering Masam. Jurnal Sumberdaya Lahan, 9(1), 37-50.

Irfan, S., Syafrimen, Y., Munzir, B., My, S., \& Fitri, E. (2019). Diseminasi hasil litbang iptek nuklir bidang pertanian di daerah sumatera barat. Jurnal Hilirisasi IPTEKS, 2(4), 369-378.

Littlejohn, S. W., \& Foss, K. (2009). TEORI KOMUNIKASI Theories of Human Communication (Sembilan). Salemba Humanika.

Mohi, K. W. (2015). Peran Bagian Hubungan Masyarakat (Humas) dalam Pengelolaan Informasi Kepada Masyarakat di Wilayah Kabupaten Bone Bolango. Jurnal Analis Kebijakan \& Informasi Publik, 1(2), 136-146.

Muljono, P. (2018). Diseminasi Inovasi Hasil Penelitian Melalui Posdaya dan Kampus-Desa Untuk Mendukung Pemberdayaan Masyarakat.

Nurhaipah, T. (2019). Komunikasi Dalam Hubungan Akrab Berdasarkan Perspektif Manajemen Koordinasi Makna. Jurnal Ilmu KOmunikasi Efek, 3(1), 27-45.

Nurhayati, Hubeis, A. V. S., Saleh, A., \& Ginting, B. (2018). Strategi Komunikasi dalam Diseminasi Inovasi Teknologi Budidaya Padi Berbasis Pemetaan Pengguna di Kabupaten Sidrap Sulawesi Selatan. Jurnal Penyuluhan, 14(2).

Nurjaman, N., Sumarwan, U., \& Kirbrandoko, K. (2016). Perilaku Dunia Usaha dalam Melakukan Adopsi Inovasi Pertanian. Jurnal Bisnis Dan Manajemen, 16(1), 29-37. https://doi.org/10.24198/jbm.v16i1.32

Oktarina, S., Hakim, N., \& Zainal, A. G. (2019). Persepsi Petani terhadap Strategi Komunikasi Penyuluh dalam Pemanfaatan Media Informasi di Era Digital. Jurnal Komunikasi Pembangunan, 17(2 SEArticles), 216-226. https://doi.org/10.46937/17201926852

Pearce, B. (1989). Communication and the human condition. Carbondale: Southern Illionis University Press.

Pearce, B. (1994). Interpersonal Communication: Making Social Worlds. HarperCollins.

Pearce, B., \& Cronen, V. (1980). Communication, action, and meaning: The creation of social realities. Praeger.

Pearce, W. B. (2009). Socially Constructing Communication. Socially Constructing Communication, 2006, $33-56$.

Putri, I. A. (2014). Peneliti dan Komunikasi Sains: The Missing Link. https://kependudukan.lipi.go.id/kajiankependudukan/peneliti-dan-komunikasi-sains-the-missing-link/

Rushendi. (2017). Komunikasi Inovasi Pertanian Bioindustri. Institut Pertanian Bogor.

Sarwoprasodjo, S. (2009). Efektivitas Iklan Politik Humas Departemen Pertanian: Politik Pertanian atau Pembentukan Ruang Publik? Jurnal Sodality, 03(03), 283-298.

Sofyan, I. (2019). Sistem Pertanian Jagung Hibrida Madura-3 Di. Jurnal Komunikasi, 13(2), 109-120.

Sugiyanto, R. D. (2016). Konstruksi Makna Humas Pemerintah Bagi Pejabat Struktural Dan Fungsional Humas. Universitas Padjajaran.

Weingart, P., \& Joubert, M. (2019). The conflation of motives of science communication - causes, consequences, remedies. Journal of Science Communication, 18(03), 1-13.

West, R., \& Turner, H. L. (2009). Pengantar Teori Komunikasi Analisi dan Aplikasi (Edisi keti). Salemba Humanika. 
Wood, T. J. (2004). Communication Theories in Action: An Introduction (Third Edit). Wadswoerth.

Zhang, Y., Wang, L., \& Duan, Y. (2016). Agricultural information dissemination using ICTs: A review and analysis of information dissemination models in China. Information Processing in Agriculture, 3(1), 17-29. https://doi.org/10.1016/j.inpa.2015.11.002 